\title{
Total spinal block, bupivacaine toxicity or else under epidural anaesthesia?
}

\author{
Total spinal blok, bupivakain toksisitesi yoksa epidural anestezi altında mı? \\ Ömer KARACA, Hüseyin Ulaş PINAR, Rafi DOĞAN
}

To the Editor,

A 65-year-old male patient with $168 \mathrm{~cm}$ height and $75 \mathrm{~kg}$ weight and medical history of $\mathrm{HT}, \mathrm{DM}, \mathrm{AF}$ and peripheral vessel disease was scheduled for femoropopliteal bypass surgery. Preoperative laboratory findings including $\mathrm{CBC}$, INR, urine examination, blood glucose and serum electrolytes were within normal limits. Before entering the operating room, patient received $500-750 \mathrm{~mL}$ of $\mathrm{NaCl} 0.9 \%$ solution via intravenous (IV) cannula and the patient was not pre-medicated. Standard monitoring including noninvasive arterial pressure (NIBP), electrocardiography (ECG), and pulse oximetry $\left(\mathrm{SpO}_{2}\right)$ was established in the operating room. The patient's baseline blood pressure was 140/80 $\mathrm{mmHg}$, pulse was $98 \mathrm{bmp}$, and $\mathrm{SpO}_{2}$ was $98 \%$. The patient was placed in a sitting position. Lignocaine $2 \%(5 \mathrm{ml})$ was infiltrated into the selected space. An 18-gauge Tuohy needle was introduced at L2-3 intervertebral space and a test dose $(1 \mathrm{cc}$ ) of lignocaine $2 \%$ was administered through the needle to confirm correct placement. The epidural space was identified using the 'loss of resistance' technique and an epidural catheter was passed through the needle. A midline approach was used under complete aseptic precautions. The anesthetic solution was prepared with $10 \mathrm{ml}$ of bupivacaine $0.5 \%$, After negative aspiration, $3 \mathrm{ml}$ of the solution was administered as a test dose. The tip of the catheter was advanced $3 \mathrm{~cm}$ cephalad beyond the tip of the needle and secured with a sterile dressing. If after 2 minutes there was no evidence of intravas- cular or subarachnoid injection, an additional $10 \mathrm{ml}$ was injected over a 1.5-minute period with fentanyl $50 \mu \mathrm{g}$. Upper and lower levels of sensory and motor block were assessed by a pinprick test and the Bromage scale, respectively. Bromage scale was 0 . When the level of sensory block reached T6, the operation was initiated. At 2 hours after starting procedure, 10 cc of bupivacaine $0.25 \%$ was administered to provide analgesia, and 20 minutes after administration, blood pressure was $60 / 40 \mathrm{mmHg}$, pulse was $45 \mathrm{bpm}$ for which the patient was administered three doses of ephedrine hydrochloride $5 \mathrm{mg}$ (edefrin, Osel), atropine sulfate $0.5 \mathrm{mg}$ (atropin, Biofarma) and adrenaline $0.5 \mathrm{mg}$ (adrenalin, Biofarma) intravenouslty. Due to persistence of hypotension, steradin infusion was started at a rate of $15 \mu \mathrm{g} / \mathrm{kg} / \mathrm{min}$. The patient had difficulty in breathing and speaking and $\mathrm{SpO}_{2}$ decreased to $70 \%$ despite mask-ventilation. The patient was intubated using propofol and recuronium. The result of $A B G$ (Arterial Blood Gas) was as follows: $\mathrm{pH}: 7.21$, $\mathrm{pCO}_{2}: 31.5 \mathrm{mmHg}, \mathrm{pO}_{2}: 70.8 \mathrm{mmHg}$, Base excess: -6.1 $\mathrm{mmol} / \mathrm{L}$, and $\mathrm{HCO}_{3}: 17.7 \mathrm{mmol} / \mathrm{L}$. After the operation, the patient was moved to the intensive care unit on mechanical ventilator. Laboratory tests were normal. The need for vasopressor therapy was assessed according to blood pressure and the need for mechanical ventilator support was assessed according to the results of arterial blood gases and the patient was extubated 1 hour after. When the patient regained consciousness, he reported rifampicin allergy. When the surgeon reported that the site of surgery was irrigated with an abundant of rifampicin during epi-

Department of Anaesthesiology and Reanimation, Başkent University Faculty of Medicine, Konya, Turkey

Submitted: 26.02.2016 Accepted after revision: 29.09.2016 Available online date: 28.12.2016

Correspondence: Dr. Ömer Karaca. Başkent Üniversitesi Konya Uygulama ve Araştırma Hastanesi, Hocacihan Mah., Saray Cad., No.1, Selçuklu, Konya, Turkey. Phone: +90 - 332 - 2570606 e-mail: dromerkaraca@hotmail.com

(c) 2017 Turkish Society of Algology 
dural analgesia, the condition was realized to be an anaphylactoid reaction. Rifampicin allergy was confirmed by the development of urticarial papules on the skin after intradermal injection of diluted rifampicin using a method reported by Cnudde F et al. ${ }^{[1]}$

Bradycardia, hypotension, apnea ${ }^{[2]}$ that occurred after epidural bupivacaine administration were considered to be associated with high spinal block or subdural block that occurred by the spread of local anesthetic into subarachnoid space or subdural space, respectively. Hence the patient was made endotracheal intubation and iv inotropic, vasopressor agents were applied as soon as possible. Boezaart AP and Thorburn JR. reported that a patient developed accidental total spinal anaesthesia, 75 minutes after administration of epidural anaesthesia, despite precautions to prevent this complication. ${ }^{[3]}$ So we primarily thought that total spinal block was developed. We also considered that bupivacaine could have rapidly passed into the vascular circulation and developed hypotension; however, rapid absorption was ruled out due to absence of accompanying ventricular fibrillations such as dysrhythmias, bradyarrhythmias and atrioventricular block and signs of central nervous system toxicity. ${ }^{[2]}$

On the other hand the drugs cause allergic reactions usually through a single mechanism. Type 1 allergic reactions are mediated by drug-specific IgE involving angioedema and anaphylaxis. ${ }^{[4]}$ Anaphylactic reaction occurring within minutes after rifampicin administration involves bronchospasm, urticaria, and hypotension with or without angioedema sometimes accompanied by erythroderma. ${ }^{[5]}$

This case which led to many diagnostic confusion was actually a drug allergy reaction. The anesthesiologists are clinicians most commonly encountering anaphylaxis during their routine practice. However, the diagnosis of anaphylaxis is very often overlooked when the symptoms of anaphylaxis are atypical or similar to the symptoms of other complications. $^{[6]}$

Our aim with this case report was to demonstrate that anaphylactic reaction can develop by cleaning of surgical site using rifampicin during hip, knee replacement or vascular bypass surgery performed under regional anesthesia as well as during wound dressings, and the symptoms of anaphylaxis are confused with the complications of regional anesthesia and local anesthesia, and we attempted to draw attention to the importance of preoperative examination and that life-saving maneuvers can be made with careful patient monitoring and prompt and accurate intervention.

\section{References}

1. Cnudde F, Leynadier F. The diagnosis of allergy to rifampicin confirmed by skin test. Am J Med 1994;97(4):403-4.

2. Alici HA, Cesur M, Kürşad H, Doğan N, Yüksek MŞ. Possible Subdural Block during Interscalene Brachial Plexus Block: A Case Report. Eurasian J Med 2008;40(2):98-101.

3. Boezaart AP, Thorburn JR. Accidental total spinal block--a complication of epidural anaesthesia. A case report. S Afr Med J 1987;71(9):596.

4. Anderson JA. Allergic reactions to drugs and biological agents. JAMA 1992;268(20):2844-57.

5. Martínez E, Collazos J, Mayo J. Hypersensitivity reactions to rifampin. Pathogenetic mechanisms, clinical manifestations, management strategies, and review of the anaphylactic-like reactions. Medicine (Baltimore) 1999;78(6):3619.

6. Graber ML, Franklin N, Gordon R. Diagnostic error in internal medicine. Arch Intern Med 2005;165(13):1493-9. 